\title{
FAKTOR-FAKTOR YANG MEMPENGARUHI INCOME SMOOTHING PADA INDUSTRI BARANG KONSUMSI YANG TERDAFTAR DI BURSA EFEK INDONESIA PERIODE 2014 - 2016
}

\author{
Eviyanti Rosalie \\ Universitas Tarumanagara \\ eviyantirosalie@ymail.com \\ Michelle \\ Universitas Tarumanagara \\ michellegouw09@gmail.com \\ Henryanto Wijaya \\ Universitas Tarumanagara \\ henryanto.wijaya@gmail.com \\ Susanto Salim \\ Universitas Tarumanagara \\ stsalim@yahoo.com
}

\begin{abstract}
:
The purpose of this study is to empirically examine the influence of return on asset, debt to equity ratio, net profit margin and firm size towards income smoothing in consumer goods listed in Indonesia Stock Exchange from period 2014 - 2016. This study used 27 data from manufacture companies that have been selected using purposive sampling method with total 81 data for three years. The data used are secondary data in the form of financial statements. This research used Statistical Product and Service Solution (SPSS) version 19 software to process the data. The result of research shows that return on asset, net profit margin and firm size have no influence towards income smoothing. Debt to equity ratio has negative significant influence towards income smoothing.
\end{abstract}

Keywords: Return on Asset, Debt to Equity Ratio, Net Profit Margin, Firm Size, Income Smoothing.

\section{PENDAHULUAN}

Perataan laba merupakan tindakan yang dilakukan oleh manajemen untuk menstabilkan laba yang berfluktuaktif. Laporan keuangan merupakan cerminan akan bagaimana kinerja setiap perusahaan yang nantinya laporan keuangan tersebut akan digunakan oleh pihak eksternal dalam pengambilan keputusan. Dalam laporan keuangan salah satu yang menjadi pusat perhatian pihak eksternal adalah laba sehingga untuk setiap perusahaan laba akan digunakan sebagai 
parameter untuk mengukur kinerja manajemen perusahaan.

Menurut Ikatan Akuntansi Indonesia ( IAI ), 2009: 2 menyatakan bahwa "manfaat lain dari informasi laba yaitu: untuk menilai perubahan potensi sumber daya ekonomis yang mungkin, dapat dikendalikan di masa depan, menghasilkan arus kas dari sumber daya yang ada; dan untuk perumusan pertimbangan tentang efektivitas perusahaan dalam memanfaatkan tambahan sumber daya." Oleh sebab itu laba mempunyai peranan yang sangat penting dan signifikan dalam proses pengambilan keputusan oleh para pengguna laporan keuangan terutama bagi pihak eksternal, karena hal tersebut maka manajemen akan berusaha untuk bagaimana mengolah pendapatan yang diperolehnya agar membuat entitas tersebut terlihat bagus secara finansial.

Dengan adanya tujuan tersebut maka perusahaan membentuk manajemen perusahaan yang dimana manajemen perusahaan memiliki kepentingan untuk melaporkan keuangan perusahaan. Setiap perusahaan pasti memiliki resiko atas setiap laporan keuangan yang akan disajikan tersebut yang nantinya hasil dari laporan keuangan perusahaan dapat berpengaruh kepada keputusan pengguna laporan keuangan tersebut. Sehingga, dalam hal ini umumnya prusahaan akan berusaha bagaimana caranya agar dapat mencegah terjadinya resiko yang nantinya akan berdampak negatif bagi perusahaan. Untuk mencegah hal itu maka pihak manajemen akan secara tidak sadar memilih untuk melakukan perataan laba karena dengan adanya laba yang stabil maka akan mencerminkan kinerja perusahaan yang baik pula, lain hal nya jika laba suatu perusahaan tersebut terlalu fluktuaktif yang nantinya akan menimbulkan kecurigaan bagi pengguna laporan keuangan yang nantinya akan berdampak pada perusahaan, menurut Sumtanky (2007) menyatakan bahwa "Income Smoothing (perataan laba) merupakan salah satu cara yang dilakukan oleh manajer untuk memanipulasi laba."

Oleh sebab itu maka ada beberapa faktor yang diduga mempengaruhi perataan laba yaitu Return on asset, Debt to equity ratio, Net profit margin dan Firm size. Faktor-faktor 
tersebut merupakan beberapa faktor yang telah dipilih oleh peneliti untuk melihat apakah ada pengaruh antara variabel Return on asset, Debt to equity ratio, Net profit margin dan Firm size terhadap perataan laba.

\section{TELAAH LITERATUR}

Agency Theory menjelaskan tentang hubungan antara pemegang saham sebagai prinsipal dan manajemen sebagai agen, dimana pemegang saham adalah pihak yang memperkerjakan manajemen untuk melakukan tugas demi kepentingan pemegang saham, sedangkan manajemen adalah pihak yang di kontrak untuk menjalankan kepentingan pemegang saham. Dalam teori keagenan ini, hubungan baik antara prinsipal dan agen sulit tercipta karena adanya perbedaan kepentingan antara satu dengan yang lain. Adapun cara yang dapat dilakukan untuk mengurangi konflik dari perbedaan kepentingan dalam teori keagenan ini antara lain menurut Masdupi (2005) yaitu dengan meningkatkan bagian kepemilikan saham manajemen sehingga manajemen dapat bertindak sesuai dengan keinginan pemegang

saham. Dengan meningkatkan persentase kepemilikan, manajer menjadi termotivasi untuk meningkatkan kinerja dan bertanggung jawab meningkatkan kemakmuran pemegang saham.

\section{Income Smoothing}

Income Smoothing adalah upaya yang dilakukan secara sengaja agar fluktuasi pada tingkat laba dapat diperkecil dan dianggap normal bagi perusahaan menurut Belkaoui (2006, h. 56). Arens et al. (2015, h. 310) mengungkapkan bahwa "perataan laba merupakan salah satu bentuk pengaturan laba dimana pendapatan dan beban ditukar-tukar diantara periode-periode untuk mengurangi fluktuasi laba." Berdasarkan uraian diatas, maka dapat disimpulkan bahwa income smoothing yaitu tindakan yang secara sengaja dilakukan untuk meminimalkan fluktuasi laba pada tingkat yang normal bagi perusahaan dengan cara mengalokasikan biaya-biaya atau pendapatan-pendapatan dari satu periode ke periode yang lain.

\section{Return on Asset}


Menurut Hanafi (2007:159), "Return on assets mengukur kemampuan perusahaan menghasilkan laba dengan menggunakan total aset (kekayaan) yang dimiliki perusahaan setelah disesuaikan dengan biayabiaya untuk mendanai aset tersebut." Return On Assets merupakan salah satu rasio profitabilitas yang menunjukkan kemampuan suatu perusahaan dalam menghasilkan laba dari aktiva yang dimiliki perusahaan. Para investor menggunakan ROA agar dapat mengetahui berapa besar return yang akan diterima pada masa yang akan datang. ROA yang tinggi menunjukkan bahwa perusahaan semakin efektif dalam memanfaatkan aktiva yang dimilikinya untuk menghasilkan laba bersih setelah pajak, yang dapat disimpulkan bahwa kinerja perusahaan semakin efektif.

\section{Debt to Equity Ratio}

Menurut Sjahrial (2009), Debt to equity ratio adalah rasio yang menggunakan aktiva dan sumber dana perusahaan yang memiliki biaya tetap, artinya sumber dana yang berasal dari pinjaman karena memiliki bunga sebagai beban tetap dengan maksud agar meningkatkan keuntungan potensial pemegang saham. Perusahaan yang mempunyai biaya tetap atau beban tetap dapat mengakibatkan resiko yang buruk bagi perusahaan. Hal tersebut terjadi karena beban bunga yang harus dibayarkan oleh perusahaan semakin membesar sehingga laba yang dapat dihasilkan perusahaan akan semakin berkurang. Jadi perusahaan yang memiliki risiko keuangan yang tinggi akan lebih sulit melakukan income smoothing karena laba yang diperoleh digunakan terlebih dahulu untuk membayar kewajibankewajibannya.

\section{Net Profit Margin}

Menurut Dewi, Sugiarto dan Susanti (2017, h. 326), “Net Profit Margin adalah rasio untuk mengukur persentase setiap penjualan yang menghasilkan laba, yang dihitung dengan membagi laba bersih dengan penjualan bersih, semakin besar Net Profit Margin (NPM) makin baik karena menunjukkan efisiensi perusahaan, namun perlu diperhatikan orientasi efisiensi yang dilakukan perusahaan bersifat jangka pendek atau jangka panjang”. Dari 
definisi diatas, maka dapat Apabila suatu perusahaan disimpulkan bahwa semakin besar mempunyai total aset yang besar, Net Profit Margin, berarti semakin efisien perusahaan tersebut dalam mengeluarkan biaya-biaya sehubungan dengan kegiatan operasinya. Jadi semakin tinggi laba bersih yang diperoleh perusahaan maka perusahaan cenderung melakukan perataan laba.

\section{Firm Size}

Ukuran perusahaan seringkali ditentukan berdasarkan besarnya aset yang di miliki perusahaan dan tingkat penjualan (Seftianne, 2011). maka perusahaan tersebut merupakan perusahaan besar dan memiliki kinerja perusahaan yang berkembang dan mudah dalam mengakses menuju pasar modal sehingga mendorong investor berinvestasi pada perusahaan tersebut. Dengan kata lain, ukuran perusahaan yang besar cenderung akan menghasilkan laba yang lebih besar sehingga membuat investor tertarik. Berhubungan dengan hal tersebut maka akan memudahkan perusahaan dalam melakukan income smoothing.

Kerangka pemikiran dalam penelitian ini yaitu

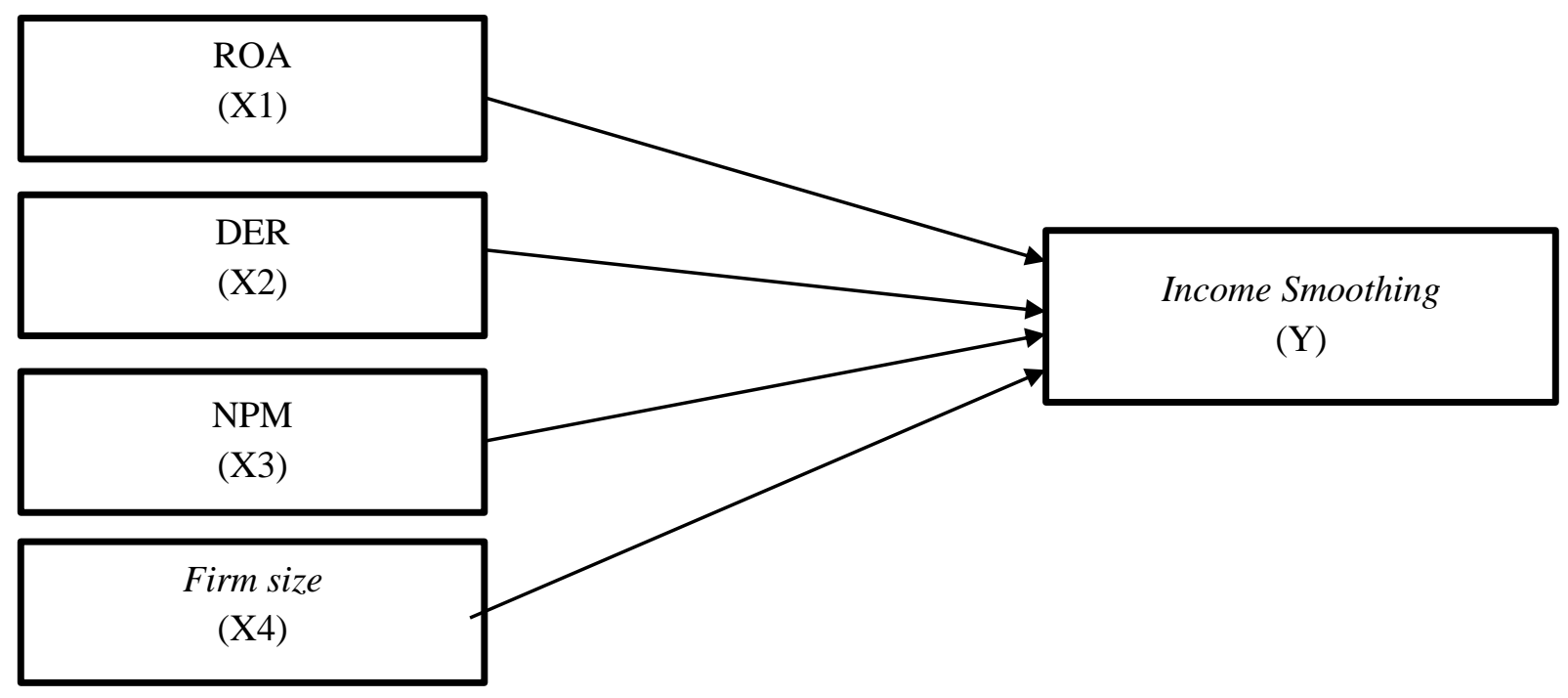

Gambar 1. Kerangka Pemikiran 
Hipotesis dari kerangka pemikiran di atas adalah sebagai berikut :

$\mathrm{H}_{1}$ : Return on asset berpengaruh positif signifikan terhadap income smoothing

$\mathrm{H}_{2}$ : Debt to equity ratio berpengaruh negatif signifikan terhadap income smoothing

$\mathrm{H}_{3}$ : Net profit margin berpengaruh positif signifikan terhadap income smoothing

$\mathrm{H}_{4}$ : Firm size berpengaruh positif signifikan terhadap income smoothing

\section{METODOLOGI PENELITIAN}

Populasi yang digunakan dalam penelitian ini adalah perusahaan consumer goods yang terdaftar di Bursa Efek Indonesia (BEI) periode 2014-2016. Pengambilan sampel digunakan dengan metode purposive sampling. Purposive sampling yaitu teknik pengambilan sampel yang dilakukan secara sengaja sesuai dengan kriteria sampel yang diperlukan. Dalam penelitian ini, kriteria yang diperlukan adalah: a) Perusahaan yang mempublikasikan laporan keuangan tahunan yang berakhir pada 31 Desember tahun
2014-2016, b) Perusahaan yang menggunakan mata uang rupiah dalam laporan keuangannya, c) Perusahaan yang IPO dibawah tahun 2015, d) Perusahaan yang tidak mengalami kerugian selama kurun waktu tahun 2013-2016 dan e) perusahaan yang mencantumkan audit report. Berdasarkan kriteria diatas, diperoleh sampel sebanyak 68 perusahaan.

Operasi variabel dalam penelitian ini terdiri dari dua variabel yaitu variabel independen yang berkaitan dengan variabel dependen. Variabel dependen yaitu income smoothing. Variabel independen yaitu return on asset, debt to equity ratio, net profit margin dan firm size.

Income smoothing merupakan suatu proses manipulasi laba agar laba yang dilaporkan terlihat stabil. Dengan ini, peneliti menggunakan Index Eckel (1981) dalam menguji variabel dependen. Index Eckel digunakan untuk mengetahui ada tidaknya indikasi tindakan perataan laba yang dilakukan oleh suatu perusahaan. Menurut Eckel (1981), Income Smoothing dapat dihitung dengan rumus

$$
\text { Index Eckel }=\frac{\mathrm{CV} \Delta \mathrm{I}}{\mathrm{CV} \Delta \mathrm{S}}
$$


Return on asset merupakan rasio profitabilitas yang menunjukkan kemampuan perusahaan dalam menghasilkan laba dari aktiva yang dimiliki perusahaan. ROA dapat dihitung dengan membandingkan laba bersih setelah pajak dan total aktiva yang dimiliki perusahaan. Rumus ROA adalah sebagai berikut (Yuliani, 2007)

$$
\mathrm{ROA}=\frac{\text { net income }}{\text { total aset }} \times 100 \%
$$

Menurut Kasmir (2009), Debt to tersebut atau hutang terhadap equity ratio adalah rasio untuk struktur modal sehingga leverage mengetahui seberapa besar berfungsi sebagai pembanding antara kemampuan perusahaan dalam total hutang dengan total modal. membayarkan seluruh kewajibannya. Rumus yang digunakan untuk Debt to equity ratio juga mengukur leverage Menurut Fahmi menjelaskan sejauh mana suatu (2012) adalah sebagai berikut: perusahaan menggunakan kewajiban

$$
\mathrm{DER}=\frac{\text { total liabilities }}{\text { total } \text { equity }} \times 100 \%
$$

Net profit margin merupakan rasio yang dapat mengukur sejauh mana kemampuan menghasilkan laba bersih pada tingkat penjualan tertentu. rumus untuk menghitung NPM adalah

$$
\mathrm{NPM}=\frac{\text { laba bersih setelah pajak (EAT) }}{\text { total penjualan }} \times 100 \%
$$

Firm size merupakan skala besar memiliki peluang yang besar dalam kecilnya suatu perusahaan yang bertahan di suatu industri karena ditentukan dari total aset. Perusahaan lebih mudah dalam memperoleh yang mempunyai ukuran yang besar pinjaman dari kreditur. Menurut lebih mudah untuk memasuki pasar Ghozali (2016), ukuran perusahaan modal sehingga perusahaan tersebut dirumuskan sebagai berikut:

Firm Size $=$ Ln of totals assets

\section{HASIL \& ANALISIS}

Uji statistik memberikan gambaran umum mengenai variabel yang diteliti berupa nilai rata-rata (mean), maximum, minimum, dan standar deviasi. Hasil statistik deskriptif 
untuk variabel return on asset (ROA) selama tahun 2014-2016 memiliki nilai mean sebesar 0.1373 , nilai maksimum sebesar 0.43 , nilai minimum sebesar 0.02 , dan standar deviasi sebesar 0.10489. Variabel debt to equity ratio (DER) selama tahun 2014-2016 memiliki nilai mean sebesar 0.7689 , nilai maksimum sebesar 3.03 , nilai minimum sebesar 0.07 , dan nilai standar deviasi sebesar 0.58883 . Variabel net profit margin (NPM) selama tahun 2014-2016 memiliki nilai mean sebesar 0.1011 , nilai maksimum sebesar 0.33 , nilai minimum sebesar 0.01 , dan nilai standar deviasi sebesar 0.06941 . Variabel firm size (SZ) selama tahun 2014-2016 memiliki nilai mean sebesar 28.7227, nilai maksimum sebesar 32.15, nilai minimum sebesar 25.80 dan nilai standar deviasi sebesar 1.61778 .

Pengujian penelitian ini menggunakan analisis binary logistic regression, secara serentak untuk keempat variabel yaitu return on asset, debt to equity ratio, net profit margin dan firm size. Analisis binary logistic regression digunakan untuk menguji mengenai kemungkinan variabel terikat dapat dijelaskan melalui variabel bebas. Penelitian ini menggunakan binary logistic regression sehingga tidak memerlukan asumsi normalitas, heteroskedastisitas, dan autokorelasi, dikarenakan variabel terikat yang terdapat pada regresi logistik merupakan variabel dummy (0 dan 1), sehingga residualnya, tidak memerlukan ketiga pengujian tersebut.

Case Processing Summary merupakan output pertama pada regresi logistik yang berfungsi menghilangkan variabel yang tidak diperhitungkan dalam model. terlihat bahwa nilai $\mathrm{N}=81$ dan percent $=$ 100 yang berarti seluruh data telah masuk dan diterima. Tidak ada missing cases (data yang hilang) dalam data pengolahan sehingga data yang akan diolah dapat dilanjutkan.

Menilai Keseluruhan Model (Overall Model Fit). Uji -2 Log likelihood Test yang dilakukan ini adalah pengujian kelayakan model (overall model fit) dan dinyatakan bahwa apabila terjadi penurunan angka -2 Log likelihood awal ke -2 Log likelihood akhir, maka hal ini menunjukkan model regresi yang 
baik. Penelitian ini menunjukkan bahwa Block Number $=0$ (awal) mempunyai nilai -2 Log likelihood sebesar 106.783, sedangkan Block Number $=1$ (akhir) mempunyai nilai -2 Log likelihood sebesar 85.993, sehingga penurunan yang terjadi adalah sebesar 20.790. Penurunan ini menunjukkan bahwa model regresi lebih baik setelah keempat variabel independen yaitu return on asset, debt to equity ratio, net profit margin dan firm size masuk ke dalam model regresi serta cocok digunakan dalam penelitian.

Omnibus Test of Model Coefficient menurut (Hyeoun-Ae, 2013) digunakan untuk mengetahui signifikansi pengaruh return on asset, debt to equity ratio, net profit margin dan firm size terhadap income smoothing. Dari output dalam penelitian ini, terlihat nilai Chi-square sebesar 20.790 dengan $\operatorname{sig}=0.000(<0.05)$, sehingga melalui pengujian signifikansi di atas, maka dapat disimpulkan bahwa return on asset, debt to equity ratio, net profit margin dan firm size secara simultan memiliki kontribusi yang signifikan terhadap income smoothing.
Hosmer and Lemeshow test digunakan untuk mengetahui kelayakan model yang digunakan. hasil uji Hosmer and Lemeshow's Goodness of Fit Test yang menunjukkan nilai Chi-square nya adalah 13.222 dengan nilai signifikan ( $p$-value) sebesar 0.104 yang berarti nilai signifikan ( $p$-value) lebih besar dari 0.05. Hal ini menggambarkan model mampu memprediksi nilai observasi serta terdapat kecocokan model dengan data aslinya dan model regresi cocok untuk digunakan ke analisis selanjutnya.

Menilai Koefisien Determinasi (Nagelkerke's $R \quad$ Square), nilai Nagelkerke R Square sebesar 0.309 yang berarti besaran variasi yang dihasilkan oleh return on asset, debt to equity ratio, net profit margin dan firm size terhadap income smoothing adalah 0.309 atau sebesar $30.9 \%$. Sedangkan sisanya sebesar $69.1 \%$ dapat dijelaskan dengan variabilitas dari variabel dependen lainnya yang tidak diuji dalam penelitian ini.

Uji Ketepatan Prediksi (Classification Table), dapat disimpulkan bahwa dari jumlah 27 perusahaan consumer goods setiap tahunnya, atau 81 sampel dalam 
kurun waktu 3 tahun (2014-2016), 30 sampel perusahaan consumer goods melakukan praktik perataan laba (income smoothing), sedangkan 51 sampel perusahaan consumer goods tidak melakukan praktik perataan laba (income smoothing). Sehingga dapat dikatakan bahwa berdasarkan hasil pengujian di atas, sampel yang diprediksi benar presentase nya adalah sebesar $67.9 \%$, nilai ini lebih dari $50 \%$ atau mendekati $100 \%$ yang artinya model ini mempunyai kemampuan prediksi yang baik.

Uji multivariate (Variables in the Equation), digunakan untuk mengetahui pengaruh secara parsial antara return on asset, debt to equity ratio, net profit margin dan firm size terhadap income smoothing.

Tabel 1. Hasil Uji Multivariate

\begin{tabular}{rrrrrrr}
\hline & & \multicolumn{1}{c}{ B. } & \multicolumn{1}{c}{ S.E. } & Wald & Df & \multicolumn{1}{c}{ Sig. } \\
\hline \multirow{5}{*}{ Step 1 $^{\text {a }}$} & ROA & $-2,387$ & 5,696 &, 176 & 1 &, 675 \\
& DER & $-1,720$ &, 788 & 4,761 & 1 &, 029 \\
& NPM & $-13,106$ & 8,164 & 2,577 & 1 &, 108 \\
& Size &,- 316 &, 180 & 3,067 & 1 &, 080 \\
& Constant & 11,173 & 5,069 & 4,859 & 1 &, 027 \\
\hline
\end{tabular}

Berdasarkan hasil pada tabel 1 menyatakan bahwa variabel ROA memiliki nilai signifikan sebesar 0,675 > dari 0,05 dan log of odds akan menurun sebesar -2,387, maka dalam hal ini variabel ROA tidak berpengaruh. Variabel DER memiliki nilai signifikan sebesar 0,029 > dari 0,05 dan log of odds akan menurun sebesar -1,720, maka dalam hal ini variabel DER berpengaruh negatif. Variabel NPM memiliki tingkat siginikan sebesar 0,108 > dari 0.05 dan log off odds akan menurun sebesar -13,106, maka variabel NPM tidak berpengaruh signifikan positif. Variabel size memiliki signifikan $0,080>$ dari 0.05 dan log of odds akan menurun sebesar -0,316, maka variabel size tidak berpengaruh. Yang berarti variabel yang memiliki pengaruh signifikan negatif terhadap perataan laba adalah variabel DER. Sedangkan, variabel ROA, NPM dan Firm size tidak memiliki pengaruh terhadap perataan laba.

Berdasarkan hasil uji statistik, Uji Case Processing Summary, Uji Overall Model Fit, Uji Omnibus Test of Model Coefficient, Uji Nagelkerke's $R \quad$ Square, Uji 
Ketepatan Prediksi dan Uji persamaan regresi sebagai berikut:

multivariate maka akan membentuk

$$
\ln \left(\frac{P}{1-P}\right)=11,173-2,387 \text { ROA }-1,720 \text { DER }-13,106 \text { NPM -0,316 SIZE + e }
$$

Dari persamaan ini maka nilai konstanta sebesar 11,173 yang artinya jika 4 variabel independen yang dipilih naik 1 satuan, maka perusahaan yang melakukan perataan laba sebesar 11,173. jika variabel ROA (Return On Asset) naik sebesar 1 satuan dengan asumsi DER (Debt to Equity Ratio), NPM (Net Profit Margin) , size konstan, maka perataan laba akan turun sebesar 2,387 satuan. jika variabel DER (Debt to Equity Ratio) naik sebesar 1 satuan dengan asumsi ROA (Return On Asset), NPM (Net Profit Margin) dan size konstan, maka perataan laba akan turun sebesar 1,720 satuan. jika variabel NPM (Net Profit Margin) naik sebesar 1 satuan dengan asumsi ROA (Return On Asset), DER (Debt to Equity Ratio) dan size konstan, maka perataan laba akan turun sebesar 13,106 satuan. jika variabel size naik sebesar 1 satuan dengan asumsi ROA (Return On Asset), DER (Debt to Equity Ratio) dan NPM (Net Profit Margin) konstan, maka perataan laba akan turun sebesar 0,316 satuan.

\section{Pembahasan}

Dari hasil pengujian dengan menggunakan regresi logistik pada penelitian ini, maka diperoleh hasil bahwa ROA (Return On Asset) tidak memiliki pengaruh terhadap perataan laba pada industri barang konsumsi yang terdaftar di BEI tahun 20142016. ROA (Return On Asset) dinyatakan tidak berpengaruh. Penelitian ini sesuai dengan penelitian Erly dan Putri (2013), Asih dan Saifudin (2017) yang menyatakan bahwa ROA (Return On Asset) tidak berpengaruh negatif terhadap perataan laba. Akan tetapi hasil dari penelitian ini tidak sesuai dengan penelitian Husaini dan Sayunita (2016), Reni (2014) yang menyatakan bahwa ROA (Return On Asset) berpengaruh negatif. DER (Debt to Equity Ratio) berpengaruh signifikan negatif terhadap perataan laba pada industri barang konsumsi yang terdaftar di BEI tahun 2014- 
2016. DER (Debt to Equity Ratio) dinyatakan berpengaruh signifikan negatif. Penelitian ini sesuai dengan penelitian Prabayanti dan Yasa (2011) dan Dwiputra dan Suryanawa (2016) yang menyatakan bahwa DER (Debt to Equity Ratio) berpengaruh signifikan negatif terhadap perataan laba. Akan tetapi, hasil penelitian ini berbeda dengan penelitian Sherlita dan Kurniawan (2013), Nurliyasari dan Saifudin (2017) yang menyatakan bahwa DER tidak berpengaruh positif.NPM (Net Profit Margin) berpengaruh signifikan positif terhadap perataan laba pada industri barang konsumsi tahun 2014-2016. Hasil dari penelitian ini sesuai dengan hasil penelitian Nyoman Ayu dan Suryandari (2012) yang menyatakan bahwa NPM (Net Profit Margin) tidak berpengaruh. penelitian ini berbeda dengan penelitian Jamaluddin dan Amanah (2015) dan juga sesuai dengan penelitian Djoko Bs dan Paulus Tahu2 (2017) yang memiliki hasil penelitian NPM (Net Profit Margin) berpengaruh positif. Firm size tidak berpengaruh terhadap perataan laba pada industri barang konsumsi tahun 2014-2016. Hasil dari penelitian ini sesuai dengan penelitian Sherlita dan Kurniawan (2013) yang menyatakan bahwa ukuran perusahaan tidak berpengaruh. Berbeda dengan hasil penelitian Agung dan Dharmadiaksa (2014) yang dimana mereka mendapatkan hasil bahwa ukuran perusahaan berpengaruh positif terhadap perataan laba.

\section{KESIMPULAN}

Hasil penelitian menunjukkan bahwa return on asset, Net profit margin dan Firm size tidak berpengaruh signifikan terhadap income smoothing. Sedangkan, debt to equity ratio berpengaruh signifikan negatif terhadap income smoothing.

Variabel ROA tidak berpengaruh terhadap perataan laba pada industri barang konsumsi yang terdaftar di BEI tahun 2014-2016 karena semakin tinggi profitabilitas perusahaan maka semakin besar kemungkinan perusahaan melakukan perataan laba.

Variabel DER (Debt to Equity Ratio) berpengaruh signifikan negatif terhadap perataan laba pada industri barang konsumsi yang terdaftar di BEI tahun 2014-2016. DER (Debt to 
Equity Ratio) dinyatakan berpengaruh signifikan negatif atau dapat dikatakan bahwa DER (Debt to Equity Ratio) berpengaruh pada praktik perataan laba karena perusahaan tidak mampu memenuhi kewajibannya.

Variabel NPM (Net Profit Margin) tidak berpengaruh terhadap perataan laba pada industri barang konsumsi tahun 2014-2016. Hal ini terjadi karena apabila laba yang dihasilkan kecil dengan total penjualan yang tetap maka nilai NPM tetap rendah. Selain itu, NPM berhubungan dengan faktor-faktor biaya dan apabila dilihat kembali nilai NPM untuk sektor industri barang konsumsi cukup stabil sehingga perataan laba tidak diperlukan.

Variabel firm size tidak berpengaruh terhadap perataan laba pada industri barang konsumsi tahun 2014-2016. Menurut hasil penelitian menyatakan bahwa firm size tidak berpengaruh karena perataan laba dilakukan bukan berdasarkan besar kecilnya ukuran perusahaan melainkan apa tujuan perusahaan itu sendiri dan dalam hal ini total aset tidak dapat dijadikan tolok ukur akan besarnya suatu perusahaan.
Di dalam penelitian ini terdapat beberapa keterbatasan yaitu: 1). Peneliti hanya menggunakan 4 variabel independen yang mempengaruhi perataan laba, variabel yang peneliti gunakan yaitu ROA, DER, NPM, dan firm size. 2). Periode waktu yang diteliti hanya 3 tahun yaitu tahun 2014-2016. 3). Perusahaan yang digunakan dalam penelitian ini merupakan industri barang konsumsi yang terdaftar di Bursa Efek Indonesia saja. Dan saran yang dapat diberikan adalah : 1). Diharapkan ada variabel lain selain yang sudah peneliti gunakan untuk meneliti perataan laba, dikarenakan masih banyak variabel lain yang dapat digunakan untuk penelitian selanjutnya. 2). Mencoba meneliti perusahaan lain selain yang telah diteliti oleh peneliti.

\section{DAFTAR PUSTAKA}

Agus Sartono R. 2001. Manajemen Keuangan Teori dan Aplikasi, Edisi Empat. Yogyakarta: BPFE.

Anthony, Robert N. dan Vijay Govindarajan 2005 . Management Control Systems. Salemba Empat: Jakarta 
Anwar, Sanusi. 2014. Metodologi Penelitian Bisnis. Jakarta: Salemba Empat.

Arens, A. A. et al. 2015. Auditing dan jasa assurance: Pendekatan terintegrasi. Edisi Kelima belas. Jakarta: Erlangga.

Belkaouli \& Ahmed, R. 2006. Accounting theory, Edisi kelima. Jakarta: Salemba Empat.

Brigham, Eugene $F$ dan Joel F. Houston. (2014). Fundamentals of Financial Management, 14th Edition. Mason: SouthWestern Cengange Learning.

Dang, David and Li, Zhichuan Frank and Yang, Chen 2017. Measuring Firm Size in Empirical Corporate Finance. Journal of Banking and Finance, Forthcoming.

Darsonodan Ashari. 2012. Pedoman Praktis Memahami Laporan Keuangan (Tips Bagi Investor, Direksi, danPemegangSaham). Penerbit Andi. Yogyakarta. NPM

Dewi, P. S., Sugiarto D. E., \& Susanti, M. 2017. PENGANTAR AKUNTANSI. Bogor: IN MEDIA.

Dharmastuti, Fara. 2004. Analisis Pengaruh Faktor-Faktor Keuangan Terhada Harga Saham Perusahaan Go Pulbik di BEJ. Jurnal Manajeman Vol 1 No.1. Jakarta Fakultas Ekonomi Universitas Atmajaya.
Echan Adam, Djumahir, dan Andarwati. 2015. VariabelVariabel yang Memengaruhi Rasio P/E dan Dampaknya terhadap Return Saham. Jurnal Aplikasi Manajemen Vol. 13(4). ISSN 1693-5241.

Eckel, N. 1981. The income smooting research hypothesis revisited. Abacus, 17(1), 2840.

Fahmi, Irham 2011. Analisa Laporan Keuangan. Bandung: Alfabeta.

Foster, G. 1986. Financial Statement Analysis. 2nd Ed. Englewood Cliffs. New Jersey: Prentice Hall International Inc.

Ghozali, Imam. 2016. Aplikasi Analisis Multivariate Dengan Program IBM SPSS 23. Semarang: Badan Penerbit Universitas Diponegoro.

Gitman, Lawrence J. 2012. Principles Of Managerial finance. 13th Edition. Global Edition: Pearson Education Limited.

Godfrey, J., et al. 2010. Accounting Theory (7th ed.). New York: McGraw Hill.

Harahap, Sofyan Syafri 2007. Teori Akuntansi, Jakarta: Rajawali Pers.

Harahap, Sofyan Syafri 2011, Teori Akuntansi Edisi Revisi 2011. Jakarta: Rajawali Pers.

Hartono, Jogiyanto 2008. Teori Portofolio dan Analisis Investasi. Yogyakarta: BPFE. 
IkatanAkuntan Indonesia 2009, Pernyataan Standar Akuntansi Keuangan. Jakarta: Salemba Empat

Irawati, Susan. 2006. Manajemen Keuangan. Cetakan Kesatu. Bandung: PT.Pustaka.

Kasmir. 2016. Analisis Laporan Keuangan, Cetakan Kesembilan. Jakarta: Raja Grafindo Persada.

Krismiaji, Aryani Y. Anni 2011. Akuntansi Manajemen. Edisi Kedua, Cetakan Pertama. Yogyakarta: Unit Penerbit dan Percetakan Sekolah Tinggi Ilmu YKPN.

Lofland dan Lofland dikutip oleh Lexy J Moleong, Metode Penelitian Kualitatif, bandung :Rosdakarya, 2006

Mamduh Hanafi. 2004.Manajemen Keuangan. Cetakan Pertama. Penerbit BPFE :Yogyakarta.

Munawir 2014. Analisa Laporan Keuangan.Yogyakarta:Liberty.

Munawir, S. 2010. Analisis laporan Keuangan Edisi keempat. Cetakan Kelima Belas. Yogyakarta: Liberty

Nazir, 2011. Metode Penelitian. Cetakan 6. Bogor: Penerbit Ghalia Indonesia.

Park, Hyeoun-Ae. 2013. An Introduction to Logistic Regression: From Basic Concepts to Interpretation with Particular Attention to Nursing Domain.
Pearce, A. Jhon \& Robinson, B. Richard. 2008. Manajemen Strategis, Edisi 10. Jakarta: Salemba Empat

Primanita dan Setiono (2006). Manajemen Laba : Konsep, Bukti Empiris dan Impli kasinya. Jurnal Kajian Bisnis dan Manajemen, Vol. 8 Nomor 1, Januari 2006.

Putra Astika, I.B. 2010.Teori Akuntansi: Konsep-konsep Dasar Akuntansi Keuangan. Buku Satu. Buku Ajar Pada Fakultas Ekonomi Universitas Udayana.

Rahmawati (2012). Teori Akuntansi Keuangan. Yogyakarta: Graha Ilmu.

Riahi, Ahmed dan Belkaoui.2007a. Teori Akuntansi. Buku Satu. Jakarta: SalembaEmpat

Santoso, Singgih. (2014). Statistik Multivariat, Edisi Revisi, Konsep dan Aplikasi dengan SPSS. Jakarta: PT. Elex Media Komputindo.

Scott, W. R. 2009. "Financial Accounting Theory. Fifth Edition". Pearson Prentice Hall: Toronto.

Siagian, Sondang P. (2011). Manajemen Sumber Daya Manusia. Jakarta : Bumi Aksara.

Subramanyam, KR dan Wild, John J. (2010). Analisis Laporan Keuangan. Buku Satu, Edisi Sepuluh. Jakarta: Salemba Empat. 
Sugiyono. (2013). Metode Penelitian

Kuantitatif, Kualitatif dan

R\&D. Bandung: Alfabeta.CV

Sugiyono. (2014). Metode Penelitian

Pendidikan Pendekatan

Kuantitatif, Kualitatif, dan

R\&D. Bandung: Alfabeta.

Sugiyono (2015). Metode Penelitian

Pendidikan (Pendekatan

Kuantitatif, Kualitatif dan

R\&D). Bandung: Alfabeta.

Syamsudin, Lukman. 2014.

Manajemen Keuangan

Perusahaan. PT. Gramedia

Pustaka Utama. Jakarta .

Umar, Husein, 2002, Metodologi

Penelitian, Untuk Skripsi dan

Tesis Bisnis, Jakarta: PT. Raja

Grafindo Persada. 